furnishings and dry boxes, mass spectrometers and vacuum equipment. In addition to the Isotope Information Office of the Atomic Energy Research Establishment, from which details of the isotopes available, cost, method of delivery, etc., can be obtained, Isotope Developments, Ltd., (120 Moorgate, London, E.C.2) and Tracer Processes, Ltd., (385 Oxford Street, London, W.1) are listed as consultants on radioactive tracer techniques. Three books are recommended for further information on radioactive isotopes and counting-tubes.

\section{Physiology of Rubber Tapping}

AN attempt has been made by J. P. Riches and E. G. B. Gooding (New Phytol., 51, No. 1, 1; 1952), and by E. G. B. Gooding (ibid., 1I), on the basis of work done at the Rubber Research Institute, Malaya, to give a more exact account of the forces at work and the processes involved when rubber trees are tapped for latex. The general conclusions of Arisz and Frey-Wyssling are retained in a modified form. When a trunk is first tapped, the latex is of high concentration and high viscosity. As a result of exudation at the cut surface, there is a fall in the internal pressure at the cut ends of the latex vessels ; but, because of its resistance to movement, only a small amount of latex is forced out, and the drop in pressure extends over a short length of vessel only. Even though dilution takes place in the affected region, the concentration and viscosity of the latex are still so great as to offer resistance to its exudation. The resistance to movement of the latex has an effect similar to a positive turgor pressure: water is taken in slowly, and pressure release in distant parts of the vessel is delayed. Hence the slow exudation of only slightly diluted latex. These ideas are followed up in their application to subsequent tappings during which flow becomes easier, concentrations become lower, and the region affected by the exudation more extensive. Related aspects are also considered. In a further contribution (ibid., 51, No. 2,$139 ; 1952$ ), the effect of various factors on the concentration of latex is considered.

\section{Studies on the Lymnæidæ}

IN an extensive monograph entitled "Recent Lymnæidæ : their Variation, Morphology, Taxonomy, Nomenclature and Distribution", consisting of 223 pages, illustrated by 369 text-figures and 5 plates (Kungl. Svenska Vetenskab. Hand., Bd. 3, No. 1, 1951. Stockholm : Almquist and Wiksell ; London : H. K. Lewis and Co., Ltd. ; 25 kr.), Bengt Hubendick has reviewed the taxonomy and nomenclature and discussed critically the distribution of the living Lymnæidæ. As the result of a careful study of many examples of sixty-nine populations from different localities in Scandinavia, the author describes in Part $l$ the variations, considered morphometrically, of the important species Lymnaca peregra. The range of variation disclosed in the shell and reproductive crgans is truly remarkable and no doubt played its part in eausing the author to becomo a 'lumper'. All too frequently collectors, having found a fow specimens in a new locality which differ from the actual type in a few or some particulars, have erected a new species without pausing to consider the entire range of variation of the original population even in the type locality; they have also omitted to tako into account the possibility or extent of ecophenotypical variations. In Part 2 of the monograph Mr. Hubendick passes on to discuss the value and applicability of morphological characters in the determination of species. In the course of this he has examined a wido specific range of material not only from the shell but also, wherever possible, by dissection and by serial sections of the male copulatory organs. Part 3 is a critical review of the recent Lymnæids considered under biogeographical regions in the light of the preceding mass of information. Finally, a bibliographical list of the previously recorded Lymnæidæ is provided, excluding the specialized I ancinæ, which includes a number of genera and about a thousand specific names. These the author has reduced to three genera and forty species with a number of varieties. This work will remain indispensable to workers in the field for many years.

\section{Pocket Check List of Malayan Timber Trees}

IN Malayan Forest Records, No. 17, Mr. J. WyattSmith has prepared a "Pocket Check List of Timber Trees" for use by Malayan forest officers (pp. 716 ; Kuala Lumpur : Forest Department, 1952 ; 3 Malay dollars or $7 s .6 d$.$) . The list includes all trees which$ reach timber size, fixed arbitrarily at $4 \mathrm{ft}$. in girth at breast height. A limited number of common small trees, although they do not reach timber height, are included as being of importance in providing poles and firewood used locally. This publication does not suffer from the disadvantage that attends many other forestry manuals of being too bulky to be taken out into the field. Indeed, this small volume is intended as a book of reference, and its regular use should ensure that only preferred vernacular names are employed and correct symbols used for enumeration surveys and linear sampling. The book is divided into four parts as follows : list of Dipterocarps ; list of non-Dipterocarps ; alphabetical index to scientific names of all trees included in Parts 1 and 2; keys to groups and species of Dipterocarps. An interesting addition is a translation into Malay of the introductory notes to Parts 1 and 2 for the benefit of the Malay field staff of the Department of Forestry.

\section{Housing in the Tropics}

THE problem of low-cost housing in tropical areas is the main topic of the sixth bulletin in the series on Town and Country Planning published by the United Nations Department of Social Affairs. The bulletin states that the great majority of dwellings in the villages, town and cities of the tropics are woefully deficient in the essential physical and social requirements of shelter. Overcrowded, structurally unsound, insanitary and infested with vermin, they lack the simplest arrangements for cooking and storing food or for washing; they are far removed from the most modest concept of standards of legally established minima. The bulletin also presents articles on design and construction for tropical housing, suggestions for improving sanitation in tropical areas and examples of how numerous communities have achieved better housing through 'self-help' projects. International activities in the field of tropical housing are reviewed in a section covering actions taken by the United Nations and several Specialized Agencies, technical assistance given by the United Nations and other organizations, and housing discussions at recent international or regional conferences.

\section{Manchester Public Libraries: Annual Report for} $1951-52$

The hundredth annual report of the Manchester Public Libraries Committee, covering the year ended 